\title{
Psychological affectation in child maloclutions
}

\begin{abstract}
In recent years, different investigations have highlighted the importance of constructing the diagnosis based on complexity in health, which implies putting the concept of comprehensive dental health in perspective. Occlusal alterations in childhood have a multifactorial etiology, considering the dental, muscular and skeletal factors of the stomatognathic complex as well as the subject in their psychism and social environment, noting the maturational development of the child, therefore this article presents an update on the affectation Psychology in child malocclusions and the impact they cause in the construction of the childhood personality.
\end{abstract}

Keywords: Psychic affectation, Malocclusions, Childhood
Volume 12 Issue 3 - 202 I

\author{
Maria N Rosende,' Alina N Peláez, ${ }^{2}$ Edna Y \\ Meza, ${ }^{3}$ Paola B Olivera ${ }^{4}$ \\ 'Deputy Professor, Chair of Psychology of the child, adolescent \\ and adult, Faculty of Dentistry of THE UNNE, Argentina \\ ${ }^{2}$ Deputy Professor, Chair Research Methodology, Faculty of \\ Dentistry of the UNNE, Argentina \\ ${ }^{3}$ Postgraduate Research Fellow, Chair Research Methodology, \\ Faculty of Dentistry of the UNNE, Argentina \\ ${ }^{4}$ Assistant Teacher, Chair Research Methodology, Faculty of \\ Dentistry of the UNNE, Argentina
}

\begin{abstract}
Correspondence: Maria N. Rosende, Faculty of Dentistry, National University of the Northeast, Liberty Avenue 5450, Corrientes - Argentina, C.P. 3400, Fax 03794- 4457992,

Email nataliarosende@hotmail.com
\end{abstract}

Received: July 01, 202I | Published: July 28, 2021

\section{Introduction}

Since dental work it is necessary to consider certain psychological aspects of the child patient that are significant in thedetection of occlusal alterations, their need to approach and treatment for the correct pediatric care. The mouth is one of the organs of the human being that intervenes most in his social relations withothers,sounfavorable psychological onsodations can cause various affectations, giving rise to certain inappropriate behaviors and attitudes in the development and well-being of the individual. ${ }^{1}$ From a complex perspective of the human being, growth and development contemplate the biological, social and psycho cognitive aspects. The interest aroused in recent years by the study of psychological and social determinants reflects a substantial change in medical thinking ${ }^{2,3}$ and invites us to question ourselvesfor the integral approach in childhood.

Currently it is very common to observe functional maloclusions in children, specifically during mixed teething. This morphological and functional abnormality of bone, muscle and dentary components can affect not only the normal functioning of the stomatopathic system such as breathing, phonation, chewing, all of which are vital functions for the development and growth of the child, directly affecting the proper psychic maturation. ${ }^{2}$ Occlusions or occlusal alterations have a multifactorial etiology, among them the most common are: tooth crowding, open bites, cross bites, little or excessive growth of the jaws among others. Each has very particular characteristics and has varying degrees of complexity to the treatment; however, they have a common appearance, usually affecting the aesthetics and psiquis of patients. ${ }^{3}$ We are interested in placing ourselves in the latter aspect since the effects on the subjective construction of the child take on a vital dimension.

Peñaranda points out the psychologicalmeaning of the mouth and face posed in various articles, expressinghowthese two areas can be white of manifestations and alterations of a psychological nature. Character alterations such as: depression, loss of sense of humor, irritability, fall of affective bonds, anhedonia (inability to obtain pleasure, loss of interest), psychomotor delay (slowness of thought, word and mimicry), feelings of disability, guilt, impotence, negative content in conversation, personal neglect, pessimism and sometimes ideasof suicide, which may be related to problems of dental type. ${ }^{4}$

Accordingly, the authors claim that the face is the mirror of the soul, beyond aesthetics, the harmony of the face is an important factor in the health and quality of life of people. ${ }^{4}$ Facial and occlusal disarmony has both physical and psychological effects on people, especially in children and adolescents. ${ }^{5}$ Occlusal alterations can make certain people shy, retracted and fearful, warning of possibilities to cause social unrest, create inferiority complexes and negative attitudes that alter their performance before the vinea. ${ }^{6}$ To establish a correct diagnosis of maloclusions it is importantto take a thorough approach that examines not only the dental, muscle and skeletal factors of the stomatognetic set but also, the individual himself in his psychic personality and social environment. ${ }^{7}$ to look into the thresholds of psychological involvement present in thechild associated with occlusal alterations introduces a unique look at establishing comprehensive approaches that contemplate multidisciplinary work in order to improve the quality of life and the proper growth of the subject.

\section{Development}

Malocclusion is often something visible that could lead to adversesocial reactions and arepresentation of itself with veryimportantcharacteristics fromwhich disadvantageous effects on the subject accrue. A small deformity in the stomatopathic system can cause psychological alterations and social discomfort in the development and well-being of the individual, and may present a car with decreased brushing and self-esteem. ${ }^{8-11}$ In the same sense studies of Meneses, D. and Botero, P., mention that aesthetic commitment during growth can generate harmful psychological effects depending on the degree of physical deformity.

Facial and occlusal alterations bring both physical and psychological effects on people, especially in children and adolescents who are going through a process of growth and maturation. The health of adolescents and young people is of great importance to all societies, as they will be fundamental elements for the drive for progress and development. ${ }^{12}$ In 
children and adolescents with malolusions, shame at their affectation can influence their school performance and subsequently their future occupation, income and social level. ${ }^{13}$ Especially young people begin to worry about their appearance, which is why orthodox treatment starts more often during adolescence, a time in life characterized by distorted self-image and overreaction towards personal-looking problems. ${ }^{14,15}$

The oral aesthetics affected as a result of certain dental alterations, brings with it negative effects on interpersonal relationships. ${ }^{1,3}$ The behavior of maloclusions worldwide ranges in ranges from 35 to $75 \%$, with a difference in sex and age. In Cuba these occur at $36.3 \%$ and the most affected sex is the female with $52.6 \%$ (16\%). According to studies carried out by porHidalgo y cols. crowdingconstitutesthe most commonanomaly, which contributes to malocclusion about 40 to 85 $\%$. Latin America exhibits high levels of incidence and prevalence of maloclusions, they occur in $85 \%$ of the child population ${ }^{17}$ This study showed how a small deformity in the stomatognetic system can cause psychological alterations and social discomfort in the development and well-being of the individual. ${ }^{6,18,19}$ Although there is no uniformity in epidemiological evaluative methods of occlusal problems, because there is no single statistical assessment that can be used by all researchers, most have agreed that 54 to $78.8 \%$ of children need orthodontic treatment at ages 12 to 18 years. ${ }^{20}$ Some authors classify these maloclusions as disabling dentofacial deformities or states that interfere with the child's overall well-being, as it can affect the dentofacial aesthetics, chewing or respiratory functions, speech or physical or psychological balance of the child. ${ }^{21}$ Other authors consider very few maloclusions to be preventable, but $25 \%$ of these can be avoided by eliminating risk factors at an early age to achieve improvement, such as deforming oral habits, these being one of the most important environmental causes of maloclusions that alter the normal function and balance of teeth and jaws. Deforming oral habits are patterns of muscle contraction of a complex nature that are learned and that when repeated become unconscious, for example: digital suction, lingual pronation, onychophagy, physychophagia, oral breathing and chewing objects. ${ }^{22}$ It might be thought that the apprehension of oral habits could sometimes be associatedwith psychic stresses and/or situations that represent a level of internal conflict for the child, the passage from isolated behavior to a habit of repetition occurs through a certain psychic energy that would not manage to be otherwise processed.

The effects of malolusions on quality of life are psychosocial in type, without the fun limitations they may present..$^{23,24}$ So these can significantly influence the perceptions of others, their behavior and their intentions to interact. ${ }^{25}$ They also pose an increased risk of psychological disadvantages and adverse social reactions that could affect people'swell-being. ${ }^{26}$

In a study in Saudi Arabia they found that children aged 11 to 14 with malocclusion had a significantly greater impact, and therefore a worse quality of life compared to a group of individuals without malocclusion. ${ }^{27}$ This result is of great importance, since most orthodontic patients are children and adolescents..$^{28,29}$ In Belo Horizonte, Brazil reports that $72 \%$ of schoolchildren were un happy with the position of their upper incisors, $21 \%$ mention that they mock them for their teeth and $8.2 \%$ of the study population had nicknames because of their teeth. ${ }^{30}$

Dentofacial anomalies represent an important social disadvantage, with a high correlation between maloclusions and low self-esteem. ${ }^{31}$ Agou and cabbage. they conducted research in which they find that the psychological profile of children with malocclusion can influence their social and emotional development, as well as their self-esteem..$^{32}$ A study in Jordan showed that children with dental and facial abnormalities are victims ofbullyng. ${ }^{33}$ Jung found that the teacher's perception of an attractive student can influence the student's expectations and assessment, employees perceived most attractive by their supervisors give them better grades in the performance of their work than less attractive employees. So those who are perceived by their teachers, peers, and employers as attractive are more likely to experience more positive social interactions and assessments. ${ }^{34,35}$

According to studies carried out by García Peláez y cols. psychological involvements are more predominant in patients with dentary abnormalities represented at $48.9 \%{ }^{36}$ These findings respond to what is published by Duke of Estrada, ${ }^{21}$ where he refers to certain types of maloclusions producing profound psychological impacts on the child; in some they affect speech and the way they behave socially, as their physical appearance makes them manifest themselves shy, withdrawn, secluded or even aggressive.

\section{Conclusion}

A comprehensive diagnosis of childhood malocclusions involves taking into account multifactorial aspects of oral health as well as the levelsof psychic involvement that certain alterations in occlusion could pose to the child in building his personality. Therefore, identify the presence of deforming oral habits froman early age, allows to perform adequate prevention by means of educational interventions that allow modifying them and thereby decrease the risk of maloclusions. Prevention is the challenge of medical care intoday's world. So the oral health tripod, quality of life and psychic condition are three dimensions that articulately allow, within the framework of primary care, tore-think about possible health interventions.

\section{Conflicts of interest statement}

There was no conflict of interest during the conduct of the study.

\section{References}

1. Oncins De Frutos M, Almodóvas Molina A. Factores psicosociales: bases para su evolución [en internet]. 2005.

2. Pérez Valdés D. Temas de Psicología. La Habana: Editorial Científico Técnica; 1999.pp

3. Alpízar Quintana R, Moráguezperelló G, Seguén Hernández J, et al. Algunas características del estado de la oclusión en niños detercer grado. MEDISAN. 2009;13(6).

4. Peñaranda Pm. Psicología odontológica: interdisciplinaridad entre la psicología y la odontología. Caracas: Universidad Central de Venezuela; 2000. p. 167

5. Martín Daza F, Pérez Bilbao J. Factores psicosociales: metodología de evaluación [en internet]. 2005.

6. Machado Martínez M, Quintana Pérez G, Grau Abalo Mr. Motivaciones y Ortod. Expectativas de los pacientes con respecto al tratamiento ortodóncico. Rev Cubana Ortod. 1995;10(2):85-95.

7. Di Santi De Modazo J, Vázquez Ub. Maloclusión Clase I: definición, clasificación, características clínicas y tratamiento [en internet]. 2004.

8. Klages U, Bruckner A, Guld Y, et al. Dental esthetics, orthodontic treatment, and oral health attitudes in young adults. Am J Orthod Dentofacial Orthop. 2004; 128 (4): 442

9. Calderón G. Influencia de seis maloclusiones en la percepción de inteligencia, atractivo físico y habilidades interpersonales. Universidad San Francisco de Quito. Tesis de grado presentada como requisito para la obtención del título de Odontóloga. Quito. 2013:2-23. 
10. Gutiérrez Y, Expósito I, Jiménez I, Et Al. Presencia de maloclusiones en adolescentes y su relación con determinados factores psicosociales. Revista Archivo Médico de Camagüey. 2008;12(5):3.

11. Meneses D, Botero P. Alternativas para el tratamiento de hipoplasias maxilares. CES Odont. 2021;25(1) 64-81.

12. Romero Mi. Curso salud y desarrollo para adolescentes. Programas y servicios de salud para adolescentes. [en Internet] 2003.

13. Bellagamba HP DE, Pearson JB. Infantile psychology applied to arthodontic. Arch Dis child. 2002;23(17).

14. SALAS MT, AGUILAR F, Arguello M, et al. Prevalencia de maloclusiones en adolescentes de 15 años del gran área metropolitana: análisis de modelos. 2005

15. Bernael De Sierra Fa. Retazos en la constitución de un sueño pedagógico (primera parte). Rev Fed Odontol Colomb. 2000;59(198):45-73.

16. SOSA ROSALES M de la C. Guías prácticas de Estomatología. La Habana: Editorial Ciencias Médicas; 2003;261-262.

17. Hidalgo Torres Y, Pavón Cruz M, Paz Quiñones L, et al. Epidemiología de las maloclusiones en niños de un área de salud de Puerto Padre. Rev Electron. 2015;40(7)

18. Moyers Re. Manual de Ortodoncia. 3 ed. Buenos Aires: Editorial Mundi. $1976 ; 170: 242-270$

19. Castillo Hernández R. Relación entre las maloclusiones y desórdenes craneomandibulares. Rev cubana Ortod. 1995;10(2):96-108

20. feregrino-Vejar Lourdes, Gutiérrez-Rojo Jaime Fabián Percepción y efectos psicosociales de las maloclusiones. Revista Tamé. 2016;4(12):443-447.

21. Duque De Estrada Riveron, Johany Y Rodriguez Calzadilla, et al. Factores de riesgo en la predicción de las principales enfermedades bucales en los niños. Rev Cubana Estomatol. 2001;38(2):111-119.

22. Téllez Peña Tm, García Jiménez Am, Menéndez Cabrera R, et al. Hábitos bucales deformantes más comunes en pacientes de la clínica docente provincial 3 de octubre, año 2012. Rev Electrón. 2014;39(10).

23. Cesarino M, Almeida T, Melo De Brito E, et al. Impact of oral health conditions on the quality of life of preschool children and their families: a cross-sectional study. Health and Quality of Life Outcomes. 2014;12:55.

24. Abanto J, Bönecker M, Raggio D. Impacto de los problemas bucales sobre la calidad de vida de niños. Rev Estomatol Herediana. 2010;20(1):38-43.

25. Calderón G. Influencia de seis maloclusiones en la percepción de inteligencia, atractivo físico y habilidades interpersonales. Universidad San Francisco de Quito. Tesis de grado presentada como requisito para la obtención del título de Odontóloga. Quito. 2013:2-23.
26. PROFFIT W, Fields H, Sarver D. Ortodóncica Contemporánea. 4ta edición. Elsevier Morsby. 2008: 16

27. Al-Sarhedd M, Bedi R, Hunt N. Ortodontic treatment need and selfperception of 11-16 years old Saudi Arabian children with a sensory impairment attending special schools. J Orthod. 2003;30(1):39-44.

28. Samsonyanová L, Broukal Z. A systematic review of individual motivational factors in orthodontic treatment:facial attractiveness as the main motivational factor in orthodontic treatment. International Journal of Dentistry. 2014;2014:1-4

29. Puentes N. Necesidad de tratamiento ortodóncico e impacto psicosocial de la estética dental en los adolescentes de la comunidad valenciana (2010). Universidad de Valencia. Tesis doctoral: fisiopatología del aparato estomatognático. Valencia. 2013:162-177.

30. Marques L, Ramos-Jorge M, Ramos-Jorge J, et al. Self perception regarding the need for orthodontic treatment among impoverished schoolchildren in Brazil. Erupean Journal of Paediatic Dentistry. 2009;10(3):125-130.

31. AGUIRRE V. Alteraciones de la autoestima provocadas por diferentes factores que influyen en la estética dentofacial y su incidencia en los estudiantes del primero, Segundo y tercero de bachillerato de los colegios "Manuel Cabrera Lozano" y "La Salle", en el periodo Abril-Septiembre 2011". Tesis previo a optar por el título de odontología. Universidad Nacional de Loja. Loja (Ecuador). 2011:52-69.

32. Agou S, Locker D, Streiner D, et al. Impact of self-esteem on the oralhealth-related quality of life of children with malocclusion. Am J Orthod Dentofacial Orthop. 2008;134(4):487-488.

33. Al-Bitar Z, Aj-Omari I, Sonbol H, et al. Bulling among Jordanian schoolchildren, its effects on school performance, and the contribution of general physical and dentofacial features. Am J Orthod Dentofacial Orthop. 2013;144(6):872-878

34. Min-Jo J. Evaluation of the effects of malocclusion and orthodontic treatment on self-esteem in an adolescent population. Am J Orthod Dentofacial Orthop. 2010;138(2):160-166.

35. Olsen J, Rohr M. Malocclusiones and perceptions of attractiveness, intelligence, personality, and behavioral intentions. Am J Orthod Dentofacial Orthop. 2011;140(5):669-679.

36. Garcia Pelaez. Afectaciones psicológicas en niños y adolescentes con anomalías dentomaxilofaciales y tratamiento de ortodoncia. Rev Hum Med. 2016;16(2):246-257. 